\title{
Performing trauma in post-conflict Northern Ireland: ethics, representation and the witnessing body
}

\section{Alexander Coupe}

\section{(c) OpenEdition}

Journals

Electronic version

URL: http://journals.openedition.org/etudesirlandaises/5143

DOI: 10.4000/etudesirlandaises. 5143

ISSN: 2259-8863

\section{Publisher}

Presses universitaires de Caen

\section{Printed version}

Date of publication: 29 June 2017

Number of pages: 105-121

ISBN: 978-2-7535-5495-5

ISSN: 0183-973X

Electronic reference

Alexander Coupe, «Performing trauma in post-conflict Northern Ireland: ethics, representation and the witnessing body », Études irlandaises [Online], 42-1 | 2017, Online since 29 June 2019, connection on 10 December 2020. URL : http://journals.openedition.org/etudesirlandaises/5143 ; DOI : https:// doi.org/10.4000/etudesirlandaises.5143

\section{cc) (†) (2)}

Études irlandaises est mise à disposition selon les termes de la Licence Creative Commons Attribution - Pas d'Utilisation Commerciale - Partage dans les Mêmes Conditions 4.0 International. 


\title{
Performing Trauma in Post-conflict Northern Ireland: Ethics, Representation and the Witnessing Body
}

\author{
Alexander Coupe \\ University of London
}

Abstract

This article evaluates the role of the body in the performance and reception of trauma testimony in post-conflict Northern Ireland. It explores how the body is exploited in public performances of nationalism and unionism, marginalised in psychoanalytic discourses around memory work, and rendered invisible within state-sponsored reconciliation processes. By contrast, the body is central to representations of truth recovery and remembrance in fictional theatre, and in the performed testimonies of applied theatre. Analysing three recent productions, this paper argues that the strategic use of the body as a site of witness facilitates an ethical form of empathy that respects the alterity of trauma.

Keywords: the body; trauma; Daragh Carville, Dave Duggan, Theatre of Witness.

\section{Résumé}

Cet article examine le rôle du corps dans les représentations artistiques ou officielles du traumatisme et dans l'impact que ces représentations peuvent avoir sur leur audience dans l'Irlande du Nord post-conflit. Il explore la manière dont le corps est exploité dans les événements publics nationalistes ou unionistes, marginalisé dans les discours psychanalytiques sur le travail de mémoire et rendu invisible dans le processus de réconciliation orchestré par l'État. A contrario, le corps joue un rôle central dans les représentations de la mémoire et la recherche de vérité dans le théâtre fictionnel ainsi que dans les témoignages personnels du théatre appliqué. Fondée sur l'analyse de trois productions récentes, cette étude montre que l'utilisation stratégique du corps en tant que site témoin $d u$ traumatisme permet une forme éthique d'empathie qui respecte l'altérité du traumatisme.

Mots clés : corps, traumatisme, Daragh Carville, Dave Duggan, Theatre of Witness.

"The truth cries out, the truth cries out/ How do we still that urgent shout?" asks Danny in couplets that form the refrain of Dave Duggan's play AH6905 $(2005)^{1}$. The voices of those who died in the Northern Irish Troubles intrude into Danny's narrative as he awaits " $[t]$ ruth recovery", a surgical examination and removal of the malignant past from his body (83). His body represents a Nor-

1. Dave Duggan, “AH6905”, Plays in a Peace Process, Derry/Londonderry, Guildhall Press, 2008, p. 85. All further references to this edition will be cited parenthetically in the text. 
thern Ireland that cannot forget the traumatic past, the dead of which haunt the present causing "spasm[s] of pain" (85). The burden of this past, and its repetition, must be broken. But, as Danny's refrain indicates, the question remains: how and for whom is one to work through such memories?

Problems arise when testimony is appropriated in ways that elide the differences between individual memory, defined by Assmann as memories that are "bound to a specific stance and are thus limited to one perspective [...] neither exchangeable nor transferable", and collective political memory formed when "embodied, homogenous and fuzzy bottom-up memory is transformed into an explicit, homogenous and top-down memory ${ }^{2 "}$. Political performances of remembrance such as Northern Ireland's annual nationalist and unionist parades use individual bodies and their testimonies to produce ideological narratives of community. What Duggan identifies as the injunction to speak of trauma can therefore become tied to collective practices that deploy the perceived incontestability of loss to sustain hegemonic structures. As representations of the conflict have become depoliticised commodities, tourist attractions in the neoliberal narrative of a post-conflict Northern Ireland open for business, personal testimonies of trauma, when not ignored in the name of maintaining public order, risk being inscribed within ethno-nationalist ideologies that homogenise the diverse experiences of Catholics and Protestants in the region.

To ask for whom the past is remembered is therefore to attend to the gap between individual memory and collective forms of political remembrance, a gap that is pronounced in the case of traumas that remain resistant even to linguistic expression. As Cathy Caruth has noted, traumatic experience cannot be symbolically encoded and overwhelms the individual's sense-making capacity. But because trauma "simultaneously demands and denies our witness" it requires a mode of representation that maintains an awareness of the ultimate inaccessibility and idiosyncrasy of that which is being communicated ${ }^{3}$. By contrast, political narratives and public demonstrations, in translating individual memories into collective political memory, often disavow this alterity.

Despite the dangers posed by the transformation of trauma into discourse, work exploring truth and reconciliation in Northern Ireland has largely focused on coming to terms with the past through storytelling ${ }^{4}$. The state's official

2. Aleida Assmann, "Memory, Individual and Collective", The Oxford Handbook of Contextual Political Analysis, Oxford, Oxford University Press, 2006, p. 213, p. 216.

3. Cathy Caruth, Unclaimed Experience: Trauma, Narrative and History, Baltimore, John Hopkins University Press, 1996, p. 5.

4. See Jo Berry et al., Ethical Principles - Storytelling and Narrative Work: relating to the Conflict in and about Northern Ireland, Belfast, Healing Through Remembering, 2009; Graham Dawson, "Life stories, trauma and the politics of memory in the Irish peace process", Memory Ireland: The Famine and the Troubles, New York, Syracuse University Press, 2014, p. 195-214; Kirk Simpson, Truth Recovery in Northern Ireland, Manchester, Manchester University Press, 2009, p. 58-76. 
methods of gathering personal testimony, from Coroner inquests to the proposed Northern Ireland Oral History Archive, rely heavily on audio recording and transcription and therefore tend to privilege language over physical expression ${ }^{5}$. This elision is understandable in a region where difference has too often been forcibly written on the body and everyday bodily practices ${ }^{6}$. The establishment of the Northern Ireland Assembly, a forum for verbal rather than physical dispute, is rightly seen as a central achievement of the peace process. However, in order to formulate an ethical approach to the staging and witnessing of trauma, we must understand how the performing body is more than merely a symptom of the absence of proper linguistic expression.

By analysing the representation of truth, reconciliation and remembering in Daragh Carville's play Family Plot (2005), Duggan's AH6905 (2005) alongside the non-fictional testimonies of Theatre of Witness, this article will outline the ways in which theatre in Northern Ireland places the body centre stage in the working through of the past. It explores both how the body bears witness to that singular aspect of trauma that cannot be transformed into discourse, that is not reducible to ideological narratives of remembrance, and how the body is also a source of empathy through which we, the collective, come to understand the trauma of the Other in relation to our own corporeal exposure. In the productions under discussion, the concomitant universality and particularity of carnal experience allows those present onstage to transmit memories that can only be partially interiorised by the audience of secondary witnesses, and that can never therefore be reduced to sectarian or state-sponsored regimes of remembrance. Caruth's declaration that attempts to convey elusive traumatic memories require a "language that is always somehow literary" should therefore be extended to consider the body, insofar as its eloquence "defies and demands" understanding, as a site of witness ${ }^{7}$.

\section{Re-enacting the past in parades and commemorations: regimes of remembrance}

The difficulty in avoiding the re-inscription of divisive ideologies in remembrance is exemplified in discussion around the process of creating a shared memorial to those who died in the Troubles. In 1999 the Cost of the Troubles Study observed that the establishment of a monument would be "premature" because "tensions still exist, and the talks process has not arrived at any settlement or

\footnotetext{
5. Northern Ireland Office, The Stormont House Agreement, London, Northern Ireland Office, 2014, p. 5.

6. See William F. Kelleher, The Troubles in Ballybogoin: Memory and Identity in Northern Ireland, Ann Arbor, University of Michigan Press, 2003, p. 80.

7. Cathy Caruth, Unclaimed Experience: Trauma, Narrative and History, op. cit., p. 5.
} 
conclusion $^{8 "}$. A decade later, the Consultative Group on the Past reached a nearidentical conclusion:

The Group does not believe that a shared memorial can be agreed at this time. It remains a contentious issue for many and poses many challenging issues around which we could not see any consensus. Who should the memorial commemorate? Should it have names inscribed and if so, whose names? What should the form of wording be? What form should the memorial itself take?

Both reports suggest that the creation of a memorial implies knowledge of the ideological shape of society before such a society has been achieved. Giving concrete form to an idea of "settlement" or "consensus" risks simplifying the difficult process of coming to terms with the past by reifying an idea of community in the present. In order to be as inclusive as possible, the precise form of consensus should be open to dispute. Consequently the idea of a "living memorial museum", a space "that can evolve" through the exchange of "living active memories", has emerged as an alternative that emphasises process rather than product ${ }^{10}$. This represents the developing understanding in Northern Ireland of collective memory as being negotiated from the bottom up out of a plurality of accounts of the past.

Such innovations developed in response to controversial remembrance practices that used the experience of wounding to consolidate ethnonationalist claims. This, in turn, fuelled the equally homogenising liberal narrative of the peace process that positioned the performance of remembrance as a threat to public order and Northern Ireland's integration into global capitalism. The persistence of old antagonisms that led to the collapse of the Assembly in 2002 resulted in a doubling of funding, between 2003 and 2005, for the Northern Ireland Victims Programme ${ }^{11}$. But this intensification of memory work was so divisive that Fintan O'Toole, writing after the resumption of devolution in 2007, still maintained that "remembrance [was] as much part of the problem as of the solution ${ }^{12 "} .2005$ in particular was a watershed year: it saw both the Police Service of Northern Ireland set up their Historical Enquiries Team to investigate equally the 3000 paramilitary murders committed during the Troubles, and the establishment of the controversial "Love Ulster" campaign to advocate on behalf of the victims of IRA violence.

8. The Cost of the Troubles Study: Final Report, Belfast, 1999, p. 42.

9. Report of the Consultative Group on the Past, Belfast, 2009 p. 104 [http://cain.ulst.ac.uk/victims/docs/consultative_grouplcgp_230109_report.pdf].

10. The Report of the Healing Through Remembering Project, Belfast, 2002, p. vi [http://cain.ulst.ac.uk/issues/victims/ docs/healremember02.pdf]. See also Cost of the Troubles, p. 103.

11. Source: CAIN website [http://cain.ulst.ac.uk/victims/docs/nialofmdfm/report_06.pdf].

12. Source: CAIN website [http://cain.ulst.ac.uk/victims/docs/newspapers/guardian/otoole_gu_210707.pdf]. 
As Susan McKay has observed, the latter group "narrated the Troubles as if it was one long IRA onslaught ${ }^{13}$ ". Their 2006 march in Dublin ended in a riot when republicans attacked participants as they walked down O'Connell Street. In the following year Sinn Féin sponsored their own "March for Truth" in Belfast to highlight police collusion. Just as with Love Ulster, the remembrance parade was widely criticised, this time for ignoring both Protestant victims of IRA violence and eliding Sinn Féin's advocacy of amnesty for ex-paramilitaries ${ }^{14}$.

As with Northern Ireland's wider parading culture - those commemorating the Glorious Revolution of 1688, The Battle of the Boyne, the Somme (for Unionists) and the 1916 Easter Rising (for republicans) - "Love Ulster" and "March for Truth" were public performances of collective political memory. Both not only attempted to monopolise to their side a sense of victimhood, excluding those bodies that did not fit such narratives, but actively used individual experiences of physical or psychological pain to perform a sense of ideological strength. The spectacle of bodies processing in an orderly and dignified way to bands playing republican and loyalist songs was designed to express the body politic's historical capacity for endurance in the face of violence ${ }^{15}$. In this way the vulnerability, exposure and dependence felt in the embodied experience of trauma was recuperated at the level of the symbolic: such feelings were merely trials to test the boundaries of the collective. Ironically, then, the very traumas caused by ethnonationalism's drive to homogenise cultural difference were themselves homogenised within ideological regimes of remembrance.

Liberal advocates of the peace process have been no less keen to discursively circumscribe the plurality of bodies involved in the performance of remembrance. As McLaughlin and Baker argue, the British and Irish news media represented "social order and pacified domesticity [...] as the preferred model of citizenship" for ensuring stability and attracting the international inward investment that constituted Northern Ireland's peace dividend ${ }^{16}$. For many commentators, divisive public remembrance was a threat to the "rational democratic organisations" that would linguistically resolve disputes and oversee the region's integration into global capitalism ${ }^{17}$.

Reporting on violent commemorations has routinely pathologised the public assembly of bodies using pseudo-psychoanalytic discourses. In his famous essay,

13. Susan McKay, Bear In Mind These Dead, London, Faber \& Faber, 2008, p. 299.

14. Ibid., p. 302.

15. Love Ulster was attended by "six loyalist flute bands" and the March for Truth "featured Republican flute bands and people dressed up as British soldiers". Alison Morris, "Fraser praises gardai", Daily Mirror [Eire Edition], 23 February, 2006, p. 23; Carissa Casey, "2,000 at Sinn Fein march", Irish Times, 13 August, 2007, p. 9.

16. Patrick McLaughlin and Stephen Baker, The Propaganda of Peace, Bristol, Intellect, 2010, p. 13; Brian Kelly, "Neoliberal Belfast: Disaster Ahead", Irish Marxist Review, 1.2, 2012, p. 47-53.

17. Tim O'Halloran, "Marchers, rioters and McDowell share the shame", Irish Examiner, 6 March 2006, n. pag. 
"Remembering, Repeating, Working Through", Freud observed that a victim of trauma "does not remember anything of what he has forgotten, but acts it out. He reproduces it not as a memory but as an action ${ }^{18 ”}$. In this schema, victims compulsively repeat the past in the present instead of properly integrating it into memory. The ameliorative abstraction of memory in narrative, for Freud, takes precedence over the compulsive re-enactments of the "motor sphere ${ }^{19}$ ". This opposition between somatic repetition and narration was adopted when in September 2005 an Orange Order parade at Whiterock, Belfast, turned into a riot. Time seemed to be out of joint, with the violence of the Troubles repeated in the streets. "Driving around Belfast" wrote Gerry Moriarty in the Irish Times, "was like driving around the city 15 or 20 years ago ${ }^{20 "}$. Such repetition was symptomatic of a past improperly assimilated into language. It was "the last resort of the chronically inarticulate", according to David McKittick, who witnessed the riot with "[a]n appalling sense of déja-vu" ${ }^{21}$ ". McKittrick did hazard a diagnosis: the failure to incorporate working class Protestants into the liberal-democratic order by delivering to them a peace dividend. For Max Hastings, however, the riots were merely a symptom of working class Protestants' "rejection of rational politics" (namely, their move away from the centrist Ulster Unionist Party). If Northern Irish society was to transcend such moments of mass hysteria, it needed to safely contain remembrance within an ordered discourse, no less than that of "modern history", where "economics [was] achieving what politics [had] not ${ }^{22 "}$. These diagnoses, in positioning somatic expression outside the domain of politics, obscured yet another inscription of the past within a different set of interests: liberal rather than loyalist.

This pseudo-psychoanalytic discourse helps explain why the embodied aspect of remembrance has been overlooked in favour of the abstraction of language. In post-conflict Northern Ireland, problematic bodies, especially in public spaces, are to be managed in order that the peace and its attendant democratic institutions be maintained. However, as Simpson has noted, this pseudo-psychoanalytic discourse is "a vacuous expediency" for "dominant political groups" hoping to stifle debate around the past ${ }^{23}$. Those losses that countermand simplistic notions of "moving on", problematize the apolitical, benign status of the past as cultural heritage, or fall outside nationalist or unionist martyrologies, are liable to be

18. Sigmund Freud, "Remembering, Repeating, Working Through", The Standard Edition of the Complete Psychological Works of Freud, Vol. 12, London, Hogarth Press, 1958, p. 150.

19. Ibid., p. 153.

20. Gerry Moriarty, "Flashback to the worst days of "war”, Irish Times, 13 September, 2005, p. 14.

21. David McKittrick, "Violence in Belfast: How a Banned March Revived the Troubles", Independent, 14 September, 2005, p. 4.

22. Max Hastings, "A Society Left Breached by History", Guardian, 15 September, 2005, p. 33.

23. Kirk Simpson, Truth Recovery in Northern Ireland, op. cit., p. 101. 
excluded both from public displays of bodies in parades and from state sponsored reconciliation initiatives. In the end, the collective interests of ethno-nationalist or neoliberal ideologies elide the individual character of trauma and its resistance to symbolic encoding.

\section{Family Plot: a critique of "talking cure"}

Drama, however, has been more critical of these pseudo-psychoanalytic understandings. Daragh Carville's tragi-comic Family Plot, staged at the Queen's Drama Centre in Belfast in the aftermath of the Whiterock riots, challenges the notion that talk alone can resolve the legacy of the Troubles in Northern Ireland. Three generations of the same family, trapped in a life-after-death purgatory, attempt to work through the past in order to reach an afterlife. Frank, a failed father, constantly reminds his fellow sufferers that: "We have to talk", "[w]e have to stick together" because "[w]e're family, aren't we? Flesh and blood ${ }^{24 "}$ ". However, in the first act, every attempt to remember turns into verbal repetitions that the participants are "powerless to stop" $(20,32,42)$. In a move redolent of the collapse of the devolved institutions, discussion only serves to re-enact well-rehearsed stories of grievance, infidelity and violence. This tendency to repeat the past verbatim results in the belated traumatisation of the next generation. Emer, Frank's daughter, arrives in purgatory at the end of the first act to affirm that those onstage are indeed metaphorical representations of Northern Ireland's intergenerational strife. She has committed suicide, unable to deal with the legacy of her father's abusiveness.

One of the play's key interventions is to foreground how Frank's insistence on talk serves to obscure a chequered past of domestic violence. His injunction to remember in order to "hold the whole bloody thing together" (18) is designed to restore a form of social relations that never existed: a golden age when Emer was born and "there was love" (47). Ideologies of remembrance like Frank's deploy nostalgia to construct an image of future reconciliation that is far too demanding given the fraught nature of the past. Worse still, his talking cure propagates a narrative of his own "impeccable behaviour" (41) based on the inaccurate and selective operations of his memory. Following the same logic as the rhetoric of order and dignity associated with parading, Frank's projection of an idealised body politic into the future cannot sustain a plurality of voices and interpretations.

Carville is suggesting that, in post-conflict societies, it is important to recognise that the effects of trauma are felt unevenly through the modalities of social

24. Daragh Carville, Family Plot, Belfast, Tinderbox Theatre Company, 2005, p. 17. All further references to this edition will be cited parenthetically in the text. 
status and gender. Not all are equal at the "talks process" table, particularly female victims of male violence. But even as the play foregrounds the dangers of strategic forgetting in verbal acts of remembrance, the use of metaphor also limits the play's ability to account for this diversity of experience. In reception it failed to resolve a tension between the symbolic resonance of the family-as-nation metaphor and individual manifestations of trauma. As Lisa Fitzpatrick has noted, the deployment of this metaphor "limits engagement with the characters as individuals: they are stock characters who stand for a group identity ${ }^{25}$ ". Carville's play also endorses equally glib clichés of forgiveness and theological intervention. When, at the end of the play, all but Frank disappear offstage to the afterlife having moved on from the past, Carville is merely replacing Frank's ideology coercive model of reconciliation with what Michael Phillips calls a "theology of reconciliation ${ }^{26 "}$. The Judeo-Christian injunction to transcend the past risks overlooking the productively disputatious task of remembering and learning to live with trauma. The play lumps all the traumas of the Troubles into one comprehensible metaphorical regime operating around ideas of familial reconciliation and the injunction to "forgive and forget" (45). This solution failed to satisfy reviewers, who variously saw Family Plot as offering "little comfort to those afraid to lay down their burden", and as caught between "specificity and universality ${ }^{27 "}$ " The ties of "flesh and blood" only function as a somewhat inadequate incarnation of Northern Irish inter-communal violence. The plurality of local and embodied experiences of trauma during the Troubles cannot be sustained when inscribed within such ideological or theological conceptions of reconciliation and remembrance.

\section{圈 $A H 6905$ and the body beyond metaphor}

Dave Duggan's play, staged in Derry/Londonderry in October 2005, attempts to resolve the tension between universality and specificity by deploying the body both as a metaphor for politics in Northern Ireland and as an intrusive material object. Truth recovery is rendered as a surgical operation conducted on Danny, the play's sole character, who, seated in a hospital waiting room, suffers from a psychosomatic illness close to Dissociative Identity Disorder (DID). The DSM-IV describes the symptoms of DID as the presence of "two or more distinct personality states that take control of behaviour ${ }^{28 "}$. The personalities that intrude on

25. Lisa Fitzpatrick, "Performing Gender, Performing Violence on the Northern Irish Stage: 'Spittin' blood in a Belfast sink", Contemporary Theatre Review, 23.3, 2013, p. 305.

26. Michael Phillips, "Aboriginal Reconciliation as Religious Politics: Secularisation in Australia”, Australian Journal of Political Science, 40.1, March, 2005, p. 111-124.

27. Grania McFadden, "Review: Family Plot", Belfast Telegraph, 4 November, 2005, p. 25.

28. American Psychiatric Association, Diagnostic and Statistical Manual of Mental Disorders: Fourth Edition, Washington DC, American Psychiatric Association, 1994, p. 484. 
Danny's narrative consist of those killed during the Troubles on all sides, from bomb casualties to victims of army violence (85).

Using DID as a model for the haunting of the past allows Duggan to depict traumas and their competing demands for justice as unmediated by a pre-emptive notion of reconciliation. Even as we are able to witness glimpses of the past in AH6905, Danny never actually remembers his own trauma onstage. Neither does he incorporate the intrusive voices of the dead into a unified sense of self - that process of reconciliation is delayed until "tomorrow" and his scheduled truth extraction (104). His performance instead becomes the medium for competing political subjectivities - the multitude of past victims demanding justice demonstrating a process of remembering that is always under negotiation. This is illustrated by Danny's moments of insecurity, such as when he finally resolves to undergo surgery so "the record can be set in stone" before mocking himself for "[a]cting like I've got it all worked out" (103). The final process of recollection remains for the audience to imagine, suggesting that what is appropriate for Danny may be different for other individuals. In order to be inclusive the process of truth recovery must not presuppose a specific form of resolution, but requires a shared commitment that itself performatively constitutes the beginnings of a postconflict political community.

Duggan's deployment of surgical procedure as a metaphor for truth extraction and, by extension, psychiatric therapy, is crucial since the body functions in the play as both a communal sign and designates the Other as Other. Jon Erickson has observed in his study of the body in performance that:

When the intention is to present the performer's body as primarily a sign, idea, or representation, corporeality always intervenes, and it is too much of a body [...] it is the "problem of other minds" which posits the "as if" of projection, but finds its identification always incomplete [...]. The body can be seen, then, both as instrument for the sign and something inexplicably $\mathrm{Other}^{29}$.

Danny's body in AH6905 certainly functions effectively as a sign. In Scene 7, for example, traumatic memory is represented as a wound, a "raw place, still oozing pus and blood" that causes pain: "the steady hum of something not properly addressed" (99). The metaphor enables the audience to translate Danny's traumatic memories - intruding as psychosomatic pain - in terms of their own experience of bodily affliction. The images of the bleeding body and Danny's "spasm[s] of pain" (88) make intelligible both the trauma of the body politic of Northern Ireland and the personal trauma of the individuals afflicted. The actor's

29. Jon Erickson, "The Body as the Object of Modern Drama", Journal of Dramatic Theory and Criticism, 5.1, 1990 , p. 242. 
body is a common sign encouraging a degree of empathic identification, where empathy entails a shared experience of corporeal vulnerability that is analogous to that performed by the Other.

Duggan is nonetheless quick to forestall any complete identification between audience - spoken to as if they are hospital visitors - and Danny. This manoeuvre has an ethical purpose. As Megan Boler has pointed out, there is often a gap between "passive empathy" and "acting on another's behalf": an audience must be incited to reform themselves and their society when confronted with the trauma of the Other, or as Danny puts it, "[i]t has to be more than just telling stories. It has to be" $(99)^{30}$. The injunction to do more than merely remember - "making sure that it doesn't happen again" (94) - is enhanced by a refusal of complete identification. Even if Danny functions as a sign for every body in the audience, so to speak, he insists on his own particularity by demanding action from them: "Don't ask me to do the truth recovery while you stand on the sidelines" (94). The spectator must not merely imagine her body as if it were Danny's but must actively seek to undergo the same process of "lift[ing] the nails out of the flesh, pris[ing] back the knuckles" (95). Danny, at one stage pointing at the audience, forces them to be conscious of their own embodied presence within the theatrical event. The stage metaphor gives way: they are no longer fictive visitors, but individuals whose singular embodied experiences are being invoked. Fundamentally Danny's body is never opened up onstage just as he never reveals the kernel of his traumatised past. Both remain, in Erickson's words, "inexplicably Other ${ }^{31}$ ".

Because the Other's body defies complete identification, performance is well equipped to resist the reification implicit in ideologies that seek to privilege one version of the traumatic past over another. The excessive corporeality of the performer's body emphasises the plurality of experiences of trauma across Northern Ireland without homogenising those experiences within a singular mode of remembrance. Duggan's staging of the body beyond metaphor challenges what Jacques Rancière calls "the essence of consensus": "the annulment of surplus subjects, the reduction of the people to the sum of the parts of the social body ${ }^{32}$ ". Just as with the idea of a "living memorial", AH6905 proposes that such abstract metaphorical conceptions of community serve to negate the presence of a multitude of witnessing bodies. The incitement to remember should concentrate intellectual resources in the hands of the individual, rather than assimilate them into a collective body, because, "in a theatre $[\ldots]$ there are only individuals plotting their own

30. Megan Boler, “The Risks of Empathy: Interrogating Multiculturalism's Gaze”, Cultural Studies, 11.2, 1997, p. 255.

31. Jon Erickson, “The Body as the Object of Modern Drama”, op. cit., p. 242.

32. Jacques Rancière, "Ten Theses on Politics", Theory \& Event, 5.3, 2001, website, [http://www.egs.edu/faculty/ jacques-rancierelarticles/ten-thesis-on-politics/] (my emphasis). 


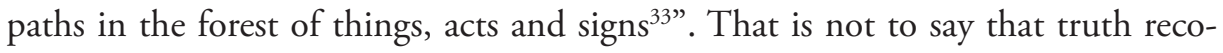
very is conducted in isolation, but that it is founded on a presumption of equality when processes of coming to terms with past wrongs are negotiated. When reminded of their corporeal specificity by Danny, the audience at $A H 6905$ have to imagine their own modes of truth and reconciliation.

\section{Theatre of Witness: negotiating the ethics of witnessing}

Theatre of Witness is an applied theatre project based in Derry and Funded through the European Union's PEACE III initiative. It was founded by American practitioner Teya Sepinuck in order to "bear witness to issues of suffering, redemption and social justice ${ }^{34 "}$. The methodology involves gathering participant testimonies and, with the collaboration of a director, editing these into a coherent production for the stage. This process of mediation is designed to prevent traumatic repetition (or re-traumatisation) by affording participants a sense of critical distance from the rawness of their memories ${ }^{35}$. As we shall see, this combination of careful mediation and real people (not dissimilar to Duggan's model) is necessitated by the political challenges of post-conflict Northern Ireland.

To date there have been six Theatre of Witness productions in Northern Ireland. We Carried Your Secrets (2009) involved recollections of growing up during the Troubles; I Once Knew A Girl (2010) explored the impact of violence towards women of both Protestant and Catholic backgrounds; Release (2012) featured an all male cast that included a former IRA volunteer and members of the security forces. Sanctuary (2013) investigated the stories of those who seek asylum in the North. Our Lives Without You (2014) centred on those who lost loved ones in the 1971 Ballymurphy Massacre. Unspoken Love (2014) staged the testimonies of those in mixed marriages. Allessia Cartoni and Thomas Spiers, two practitioners mentored in the Theatre of Witness process by Sepinuck, directed, respectively, the two most recent plays.

The process of resisting ideological co-optations of remembrance is particularly important where conceptions of the "public good" prevent individuals from properly working through the past. Cartoni's production, Our Lives Without You, is of interest because it staged the testimonies of those whose family members were murdered by the British Parachute Regiment in the 1971 Ballymurphy massacre. The fact that, unlike previous Theatre of Witness productions, the play involved only participants from the Catholic community might be construed as

33. Jacques Rancière, The Emancipated Spectator, tr. Gregory Elliot, London, Verso, 2009, p. 16.

34. Source: Theatre of Witness website, [http://www.theatreofwitness.org/about-us-2/].

35. On the use of mediation to prevent re-traumatisation see Teya Sepinuck, Theatre of Witness, London, Jessica Kingsley, 2013, p. 182. 
running counter to the demands of the PEACE III funding, designed with the stated aim of subsidising projects concerned with "reconciling communities" 36 . It is important, therefore, to consider whether, in voicing counterhistories to liberal narratives of redemption, Our Lives perpetuated republican narratives of victimhood.

Performed in Derry in 2014, Our Lives used applied theatre to bring into focus those bodies and voices that are excluded from official forms of history making. Even while the production was being devised, members of The Ballymurphy Families group exploited the explicitly performative power of such counter-memories. Faced with repeated delays to the Coroner's inquest over funding and alleged "issues of national security", they hoped to establish an independent enquiry into the massacre ${ }^{37}$. Theresa Villiers, the Secretary of State for Northern Ireland, deemed this request against "the balance of public interest $\mathrm{t}^{38}$ ". In a press conference arranged shortly before the opening night of the play, Briege Voyle, a participant in the Theatre of Witness production, publically destroyed the letter Villiers had sent the families informing them of this news ${ }^{39}$. In tearing up this metonym for the British state, Voyle refuted the graphic legitimacy of a British government whose process of dealing with crimes against the Catholic population was perceived as ideologically tainted ${ }^{40}$. Without access to the privileged mode of remembering and recording injustice Voyle resorted to a physical performance that, unlike governmental programs perceived to involve "too much bureaucracy and not enough feeling", expressed the affective persistence of trauma ${ }^{41}$.

Continuing this emphasis on stage presence, Our Lives was devised in such a way as to balance the aesthetic accessibility and resistance of the performer's witnessing body. Pat Quinn, whose brother was shot in Ballymurphy, illustrates the demand for restitution inherent in the constant physical presence of trauma: "this body wants to dance, this body wants to break free, this body wants to fly ${ }^{42}$ ". He gestures to "these eyes", "these hands", "these feet" and "this body beaten up

36. Source: Special EU Programmes Body website, [http://www.seupb.eu/programmes2007-2013/peaceiiiprogramme/ overview.aspx].

37. For "issues of national security" see BBC News website, [http://www.bbc.co.uk/news/uk-northern-ireland-20340606. See also Ballymurphy Families, Ballymurphy Independent Panel: A proposal by bereaved families, Belfast, Ballymurphy Families Campaign, website, [http://www.ballymurphymassacre.com/cms/wp-content/ uploads/2014/01/Ballymurphy_Independent_Panel.pdf] p. 3.

38. Source: Northern Ireland Office website, [https://www.gov.uk/government/news/decision-on-ballymurphy-independent-review-panel].

39. Source: BBC News website, [http://www.bbc.co.uk/news/uk-northern-ireland-27199485].

40. See Patricia Lundy, "Can the Past be Policed?: Lessons from the Historical Enquiries Team Northern Ireland", Journal of Law and Social Challenges, 11, 2009, p. 109-156.

41. Source: CAIN website, [http://cain.ulst.ac.uk/victims/docs/political_parties/apni/report_300605.pdf], p. 2.

42. Theatre of Witness, Our Lives Without You, dir. Chris McAlinden, art dir. Teya Sepinuck, prod. Alessia Cartoni, Derry/Londonderry, Cmore Films, 2014, DVD. All subsequent quotations transcribed from DVD recording of The Playhouse performance. 
by the British army" (Figure 1). In Pat's hands, history is no longer the abstraction of the Coroner's report, but is a memory of the flesh: the residue of physical pain and psychological torment. His gestures, as well as his testimony, afford the audience, in Felman's words, "the imaginative capability of perceiving history - what is happening to others - in one's own body 43 ". It is through our common predicament as bodies exposed to pain and capable of pleasure that we are able to empathise with the memories of violence and trauma Pat Quinn feels reverberating in his flesh.

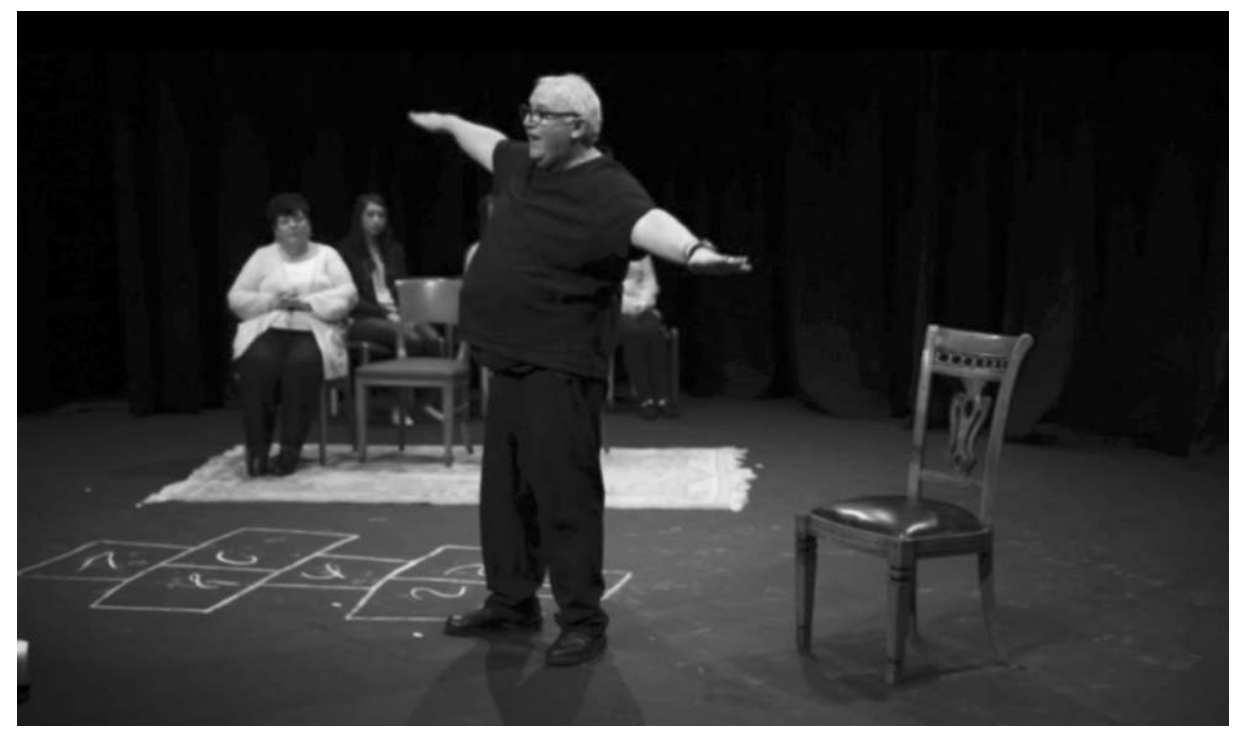

Figure 1

Demonstrations of anti-British counter-memory such as Pat's nevertheless risk being folded back into the abovementioned pain-exploiting practices that dominate the Northern Irish public sphere. For playwright Tim Loane, Theatre of Witness as a whole fails to "challenge the audience's preconceptions and prejudices" and therefore elicits a passive response:

In this process of distillation for "performance" it is nigh impossible to resist sentimentalizing and celebrating victimhood. This in effect means presenting the audience with exactly what it wants and gives them an easy way out through a hyper-emotional reflex ${ }^{44}$.

43. Shoshana Felman \& Dori Laub, Testimony: Crisis of Witnessing in Literature, Psychoanalysis and History, Abingdon, Routledge, 1992, p. 108.

44. Quoted in David Grant \& Matthew Jennings, "Processing the Peace: An Interview with Teya Sepinuck", Contemporary Theatre Review, 23.3, 2013, p. 317. 
Our Lives does indeed resort to easy clichés characteristic of "Troubles plays": the domestic space, for example, is figured in Pat Quinn and Rita Bonner's testimonies as an idealised, prepolitical realm tainted by the violence ${ }^{45}$. It does not, however, locate redemption in pacified domesticity: all the participants express both their frustration with the state's delays in recovering the truth and their anger at the British Army's actions. Moreover, Teya Sepinuck's writing on the Theatre of Witness methodology shows an awareness of the risks of passivity. Like Loane, Sepinuck hopes to encourage "active listening", not only by allowing audience members to question directorial decisions in the post-show Q\&A sessions, but also by remaining faithful to the necessity of "seeing oneself in every human", a process which, nevertheless, "can only be an aspiration ${ }^{46 "}$. In other words, even as we attempt to empathise, it is crucial to recognise that the Other always resists our frameworks of understanding.

This resistance is particularly evident in Our Lives during the testimony of Eileen Corr, daughter of Joseph Corr, a victim of the massacre. She declares that she "can't remember what happened after [her father's] death". Instead her memory is represented in the oblique tattoos Eileen drew on herself as a child (Figure 2). The body, in particular these markings, makes sensible and visible the otherness of Eileen's traumatic experience. The audience can, perhaps, imagine her grief as comparable to the physical pain of the tattoo needle. Nevertheless the meanings of such markings are never explained and perhaps cannot be made intelligible. These physical wounds are a part of Eileen's sense memory: that nonnarrative trace of past pain that is felt in her body alone. The tattoos, in their stubborn resistance to reading, are a reminder of the insistent and necessary corporeal inaccessibility of the Other.

Cartoni, as in other Theatre of Witness productions, also gives space to nonspeaking participants who, through the fact of their physical presence onstage, attest to their untold or untellable stories ${ }^{47}$. In Our Lives, Alice Taggart, whose father was also murdered in the massacre, remains largely silent and still in her chair. Her niece, Aisling Devlin, a member of "the next generation who is a witness to these stories", recalls, in her aunt's stead, what she has learned of Daniel Taggart's death. During her account she constantly refers to Alice's physical presence, what she sees rather than hears: "I see a woman who is carrying the burdens of the past" (my emphasis). Aisling observes in the body, rather than in language, her aunt's testimony, an observation that is only partial because viewed from the outside. Here, then, to be silent is not to be condemned to invisibility within a

\footnotetext{
45. See Mark Phelan, "From Troubles to Post-Conflict Theatre in Northern Ireland", Oxford Handbook of Modern Irish Theatre, Oxford, Oxford University Press, 2016, p. 374.

46. Teya Sepinuck, Theatre of Witness, op. cit., p. 231-234.

47. For example, asylum seeker Maryama Yuusuf in Theatre of Witness's 2014 production entitled Sanctuary.
} 


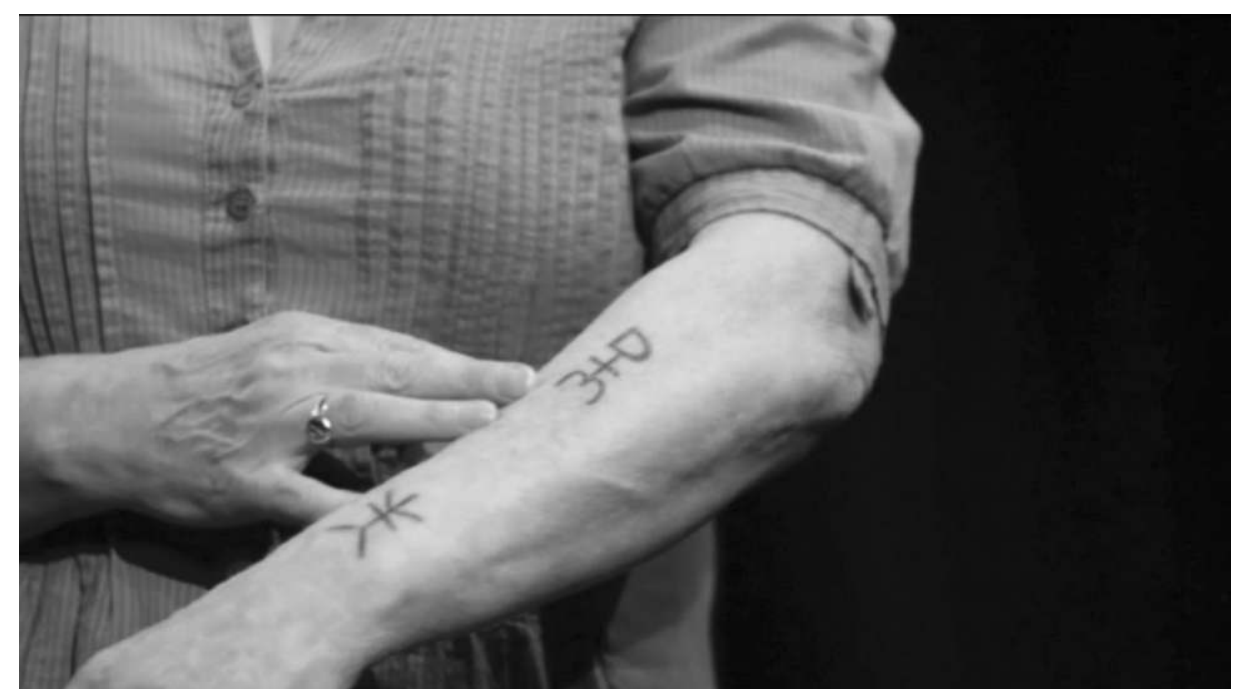

Figure 2

culture that insists on narrative remembrance. Rather, Alice's stoical presence marks a refusal to transform her memories into a discourse that the audience can passively absorb into pre-established politicised memorial narratives. The visibility of this apparently "surplus subject" also flouts the linguistic abstractions of history enacted in Villiers's letter and the Coroner's report. Even as the specificity of Alice's personal trauma remains indecipherable, her physical silence communicates the demand for a form of recognition, legitimacy and dignity unavailable in such crude accounting processes.

Sepinuck's ethics of "active listening" emerges in the audience's negotiation of such representations of stoical alterity. The feedback for Our Lives suggests that the production, by placing corporeal limits on the readability of the testimonies, avoided being uncritically inscribed within the prefabricated narratives of the two traditions. One respondent, a "Protestant from the Shankill", notes that they were "deeply touched by the stories" adding that "[w]e have all suffered way too much ${ }^{48}$ ". Such feelings of empathy transcend hierarchies of victimhood that foreclose the possibility of seeing the Other as equally vulnerable. But the responses also give a sense of how the body is paradoxically both the condition of and impediment to empathy. One observer declares the testimonies "deeply personal" and "feel[s] blessed to have been in contact with [them]" while another notes that they "didn't really understand what it must have been like for all you wonderful and

48. Source: Theatre of Witness website, [http://www.theatreofwitness.org/reflections-our-lives-without-you/]. 
brave people ${ }^{49}$ ". Like the first respondent, they talk of being moved while remarking on the alterity of the body they have been "in contact" with and moved by. This impossibility of total identification bespeaks, in other responses, the need for each individual in Northern Ireland to participate in actively processing the past: "The story-tellers become vessels for the untold stories in the larger community. As they heal they invite/inspire the rest of us to heal ${ }^{50}$ ". Audience members felt incited to act precisely because they could neither take the place of the Other, nor could the Other take theirs. And indeed audience members did end up participating in subsequent productions, answering Danny's call not "to stand on the sidelines $^{51 "}$ (94).

\section{Conclusion}

For Freud, to work through trauma is to combat its somatic symptoms, namely repetition compulsion. Talking cure is "a perpetual struggle to [...] keep in the psychical sphere all the impulses which the patient would like to direct to the motor sphere ${ }^{52}$. Making trauma visible is a question of transforming it into discourse. However, such a view simplifies the body's role in remembering. Traumatic memory is often co-opted in sectarian discourses of community and victimhood performed on the streets in the form of marches. Here, the body is not instinctually "acting out", but is disciplined within a regime of remembrance that choreographs diverse individual performing bodies into a univocal expression of belonging, or, as in Family Plot, a performative metaphorical structure: the "flesh an blood" family.

The kind of empathic identification with the Other's trauma enabled by corporeal metaphor is of course crucial in processes of reconciliation. In Theatre of Witness the body is represented as a repository of traumatic memories that are silenced within dominant regimes of remembrance. It is in our identification with the bodily pain of those like Pat Quinn and Eileen Corr that we can glimpse psychosomatic trauma and its destabilising effect on official histories. But the body also functions metonymically in relation to the irretrievable otherness of traumatic memory. It is both the expressive surface on which we read and understand the pain of another and a figure standing in for the unspeakable otherness and corporeal individuality of trauma. As discussed, its alterity has important ethical functions in post-conflict Northern Ireland. In AH6905, Danny's insistence on

\footnotetext{
49. Ibid.

50. Ibid.

51. Kathleen Gillespie performed in I Once Knew A Girl (2010) having been an audience member at We Carry Your Secrets (2009). See Teya Sepinuck, Theatre of Witness, op. cit., p. 191.

52. Sigmund Freud, "Remembering, Repeating, Working Through", op. cit., p. 158.
} 
this alterity prevents him from becoming a sacrificial figure that can be processed as a surrogate for the rest the community. Indeed such a performance of trauma calls into question the very possibility of embodying, in a single person, an idea of community because we cannot merely transcribe individual embodied memories, such as those of Our Lives, into abstract historical narratives (whether statistical, ideological, or archival) without defacing the otherness of the body. By drawing attention to the intrusive materiality and alterity of the body, theatre can nevertheless elicit an ethical form of witnessing that never allows the audience to complacently incorporate trauma. 